\title{
The Current State of Research with Human Pluripotent Stem Cells in Brazil
}

Patricia Pranke, ${ }^{1,2 ; *}$ Pedro Chagastelles, ${ }^{1}$ and Laura E. Sperling ${ }^{1}$

\section{ABSTRACT}

This article provides a brief overview of research with human pluripotent stem cells in Brazil, the federal funding supporting this research, and the legislation that allows the isolation of human embryonic stem cells.

\section{INTRODUCTION}

Pluripotent stem cells (PSCs) have been the focus of scientific research since their isolation because of their special characteristics. There are two types of PSCs: embryonic stem cells (ESCs) and induced PSCs (iPSCs). However, as the isolation of ESCs involves the destruction of embryos, research with human ESCs (hESCs) is highly controversial and requires regulation through national legislation.

\section{Overview of scientific}

\section{research with human}

\section{PSCs in Brazil}

In order to determine the number of articles where human PSCs (hPSCs) are experimentally used in Brazil, the

${ }^{1}$ Hematology and Stem Cell Laboratory, Faculty of Pharmacy, and Stem Cell Laboratory,

Fundamental Health Science Institute, Federal University of Rio Grande do Sul, Porto Alegre, Brazil.

2 Stem Cell Research Institute, Porto Alegre, Brazil.

*(Correspondence: patriciapranke@ufrgs.br)
PubMed database was searched using various combinations of key words and information was gathered from Brazilian scientists working with pluripotent cells. Key words used for searching the PubMed database were as follows: human embryonic stem cells AND Brazil, human ES cells AND Brazil, human induced pluripotent cells AND Brazil, hES cells AND Brazil, human iPS cells AND Brazil, and human pluripotent AND Brazil. More than 200 hits were obtained, and they were manually controlled in order to exclude reviews, comments, research with mouse cells, and research with adult stem cells (ASCs). Searches were performed in June 2014. Articles published online ahead of print in 2014 have been included.

Research with hPSCs in Brazil has been occurring for the last 5 years. The number of publications is still low, but a tendency of an increase has been maintained during the last few years. Thirty-five articles were identified dealing with hESCs and hiPSCs, published since 2009 in Brazil. From these articles, 10 are studies with hESCs, 12 are studies with hiPSCs, and 13 are reviews (Fig. 1). Interestingly, there are a relatively high number of reviews that deal with this topic,

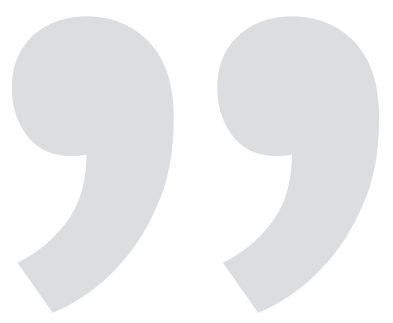

Preliminary steps toward clinical trials with human embryonic stem cells began in Brazil in cooperation between the University of Southern California in Los Angeles and Federal University of São Paulo (UNIFESP).

indicating that there is a great interest in the area.

The majority of these hSC articles describe the derivation of new lines, improved culture, or feeder-free conditions [1-4]. Most of the conducted research is basic research. The first Brazilian publication with hESCs describes a high-yield protocol for culturing hESCs in a stirred microcarrier system with commercial dextran-based microcarriers coated with denatured collagen [5]. The first milestone of research with hESCs was reached in 2011 with the isolation of the first South American hESC line, called BR-1 [1]. The article stresses the importance of the isolation of the Brazilian lines, due to the diverse ethnical background of the population. The research on peer-reviewed journals revealed that two other Brazilian $\mathrm{hESC}$ lines have been isolated until now [4]. They were called BR-4 and BR-5 and 
were established in physiological oxygen concentrations. Efforts were made to culture the hESC lines in xeno-free [2] or feeder-free conditions [3] to allow the usage of cells for clinical applications. Another part of the Brazilian publications with hESCs deals with their molecular characterization, especially of the surface sugars [6,7]. These studies show that surface sugar has an important role in the pluripotency and differentiation of hESCs. Another line of research with hESCs in Brazil deals with their tumorigenicity when used for cell therapy [8].

In 2013, preliminary steps toward clinical trials with hESCs began in Brazil [101] in cooperation between the University of Southern California in Los Angeles and Federal University of São Paulo (UNIFESP). The Brazilian group will be implanting hESC-derived retinal pigment epithelium cells in 15 Brazilian patients who suffer from macular degeneration. The cells, supplied from the United States, will be implanted as a polarized monolayer grown on a parylene membrane.

Since their isolation in 2006, iPSCs have attracted much interest in the scientific community. Brazilian scientists published their first results with hiPSCs in 2011 [9].
Following the international research trends with iPSCs, Brazilian researchers have focused on the generation of patientspecific hiPSC lines [4,10-12], such as schizophrenic or amyotrophic lateral sclerosis patients. Moreover, various types of cells have been used for reprogramming [13-15], including dental pulp stem cells (SCs) and human menstrual-bloodderived mesenchymal cells, and different reprogramming factor combinations have been proposed [9].

\section{The Brazilian law in reference to the use of human ESCS}

Two landmarks referring to the use of hESCs in Brazil occurred on March 24, 2005, and March 28, 2008.

In 2005, the Biosafety law (Lei de Biossegurança) (No. 11,105) included the approval of the use of hESCs in the following terms: "Art. $5^{\circ}$ The use of embryonic stem cells for research and therapeutic ends is permitted when obtained from *human embryos produced through in vitro fertilization but not used for the primary aim, adhering to the following conditions" (*spare embryos):

FIG. 1. Overview of published work in Brazil reporting experimental use of human pluripotent cells. Search was carried out on the PubMed database, and the results were evaluated by the authors to exclude false-positive hits. Only original articles were included in this figure.

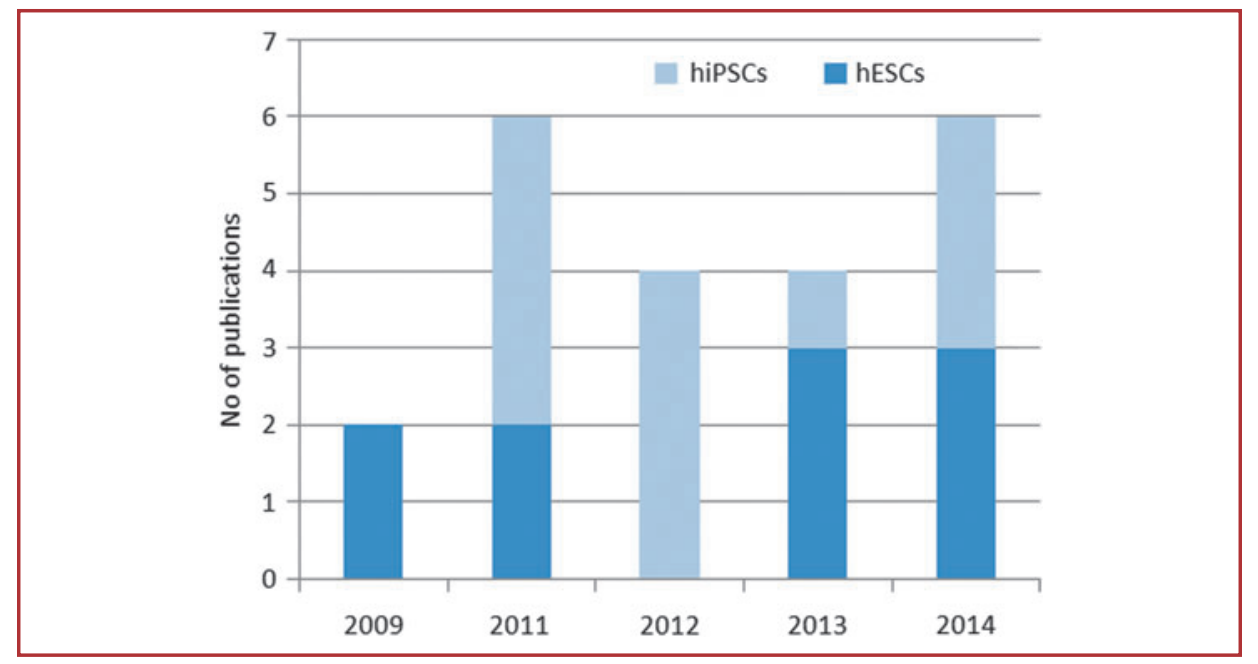

I-inviable embryos; or

II-frozen embryos for 3 (three) years or more, since the date of the publication of this law, or, if already frozen before the date of publication of this law, after the completion of a 3 (three) year period beginning from the date of freezing. $\S 1^{\circ}$ Under any circumstances, consent of the genitors is required.

$\S 2^{\circ}$ Research institutions and health services who carry out human embryonic stem cell research or therapy should submit their projects for evaluation and approval to the respective research ethics committees.

$\S 3^{\circ}$ The commercialization of biological material is prohibited, as referred to in this article and its practice constitutes a crime, in accordance with art. 15 of law $n^{\circ} 9,434$, 4th of February, 1997.

Art. $6^{\circ}$ The following is prohibited:

III genetic engineering in human germ cells, human zygotes and human embryos;

IV human cloning

Dr. Mayana Zatz and Dr. Patricia Pranke were instrumental in the drafting and process of adopting the legislation, providing scientific advice to the law makers in reference to the law quoted above.

However, after approval of the law, a federal attorney general raised the question of its constitutionalism. As a consequence of this, the question was taken to the Supreme Court for further analysis. On March 28, 2008, the Supreme Court decreed that the law was constitutional.

\section{Funding}

Brazilian funding for $\mathrm{SC}$ research began in 2002 as an initiative of the Science and Technology Ministry with the creation of the Millennium Institute of Tissue Bioengineering. Despite the fact that it was not exclusively for SC research, this grant supported projects that began working with cell therapy and SCs. At the time, there was no regulation about the use of hESCs and all the projects were dedicated to studying ASCs.

The first opening of a grant for supporting research for the use of ESCs was launched in 2005 after legal approval by the National Congress. Forty-five projects were approved for the study for all types 
of SCs, but only $13 \%$ were dedicated to studying ESCs [15]. Following the offer of this first grant, designation of the financing of which included research with hESCs, the delivery of further grants with the same purpose was delayed during the process of analysis by the Supreme Court. After the approval by the Supreme Court in 2008, the fourth opening of a grant supporting SC research was launched. A total of 52 projects, which involved basic, preclinical, and/or clinical studies and which also included hPSCs, were supported by this grant. During the same year, the Health Ministry in conjunction with Financiadora de Estudos e Projetos (FINEP) and Banco Nacional de Desenvolvimento Econômico e Social (BNDES) supported the establishment of Cell Technology Centers (CTCs) with the aim of preparing the country for clinical $\mathrm{SC}$ studies. A total of eight CTCs were created in five different states, which are now responsible for providing a variety of types of clinical-grade SCs. These include mesenchymal SCs from different sources, organ- or tissue-specific SCs (neural and cardiac SCs), and PSCs. Also in 2008, the Brazilian Network for Cell Therapy (Rede Nacional de Terapia Celular-RNTC) was created. The RNTC is composed of the 8 CTCs and 52 research laboratories distributed around the country [102]. This network was established to increase the exchange of information and promote scientific collaboration between research groups.

One of the achievements of this endeavor was the establishment of the first human ESC line by a Brazilian group in 2011 [1]. Efforts have also been made to promote internationalization of SC research as the majority of the work was being carried out in Brazil with little collaboration from abroad. Thus, in 2011 a grant was offered for the creation of the Bi-national Program of Cell Therapy to stimulate joint projects between groups from Brazil and Argentina. The seventh grant covering SC research was launched in 2012, entitled Translational Cell Therapy Research, and is currently funding 29 projects. These projects use adult and/or pluripotent SCs and include basic, preclinical, and clinical studies (type I and II clinical trials to test the safety of new procedures).

Integrating all the initiatives, a total of approximately 50 million dollars has been allocated to support seven specific grants for this research area; however, the inclusion of the other grants that have been made available, not specifically directed toward SC research, but which can also be used in this area, brings the total amount for investment to around 100 million dollars. As in other scientific areas, research in cell therapy is predominantly financed by the public sector in Brazil.

A total of $\$ 50$ million has been allocated to support grants for stem cell research in Brazil, and with the inclusion of other unspecified grants, the total amount of investment is approximately $\$ 100$ million that is available in this research area.

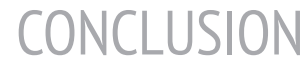

In Brazil, as in other South American countries, there is an emergence of scientific enterprise. Investments and publications are on the increase with greater resources becoming available for research. There is an impetus to attract young researchers to remain in the country, and, with corroboration from international colleagues, young scientists are carrying out research abroad and returning with the benefits of additional knowledge and experience. This global collaboration is the only way to assure the real success of SC research and the transference of its benefits for the whole of society.

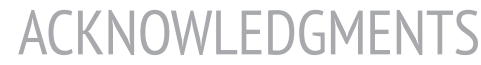

CAPES, CNPq, and Stem Cell Research Institute.
Author Disclosure

\section{Statement}

The authors declare that there are no conflicting financial interests.

\section{REFERENCES}

\section{Primary Literature}

1. Fraga AM, M Sukoyan, P Rajan, DP Braga, A Iaconelli, JG Franco, E Borges and LV Pereira. (2011). Establishment of a Brazilian line of human embryonic stem cells in defined medium: implications for cell therapy in an ethnically diverse population. Cell Transplant 20:431-440.

2. Marinho PA, DT Vareschini, IC Gomes, BaS Paulsen, DR Furtado, LoR Castilho and SK Rehen. (2013). Xeno-free production of human embryonic stem cells in stirred microcarrier systems using a novel animal/human-component-free medium. Tissue Eng Part C Methods 19:146-155.

3. Freitas ER, RL Santos, EC Lima and LA Guillo. (2013). Feeder-free culture of human embryonic stem cell line BG01V/hOG using magnetic fieldmagnetic nanoparticles system. Biomed Pharmacother 67:17-21.

4. de Oliveira Georges JA, N Vergani, SA Fonseca, AM Fraga, JC de Mello, MC Albuquerque, LS Fujihara and LV Pereira. (2014). Aberrant patterns of $X$ chromosome inactivation in a new line of human embryonic stem cells established in physiological oxygen concentrations. Stem Cell Rev 10:472-479.

5. Fernandes AM, PA Marinho, RC Sartore, BS Paulsen, RM Mariante, LR Castilho and SK Rehen. (2009). Successful scale-up of human embryonic stem cell production in a stirred microcarrier culture system. Braz J Med Biol Res 42:515-522.

6. Alisson-Silva F, D de Carvalho Rodrigues, L Vairo, KD Asensi, A Vasconcelos-dos-Santos, NR Mantuano, WB Dias, E Rondinelli, RC Goldenberg, TP Urmenyi and AR Todeschini. (2014). Evidences for the involvement of cell surface glycans in stem cell pluripotency and differentiation. Glycobiology 24:458468. 
7. Stelling MP, YM Lages, AM Tovar, PA Mourão and SK Rehen. (2013). Matrixbound heparan sulfate is essential for the growth and pluripotency of human embryonic stem cells. Glycobiology 23:337-345.

8. Suzuki DE, AM Nakahata and OK Okamoto. (2014). Knockdown of E2F2 inhibits tumorigenicity, but preserves stemness of human embryonic stem cells. Stem Cells Dev 23:1266-1274.

9. Picanço-Castro V, E Russo-Carbolante, LC Reis, AM Fraga, DA de Magalhães, MD Orellana, RA Panepucci, LV Pereira and DT Covas. (2011). Pluripotent reprogramming of fibroblasts by lentiviral mediated insertion of SOX2, C-MYC, and TCL-1A. Stem Cells Dev 20:169-180.

10. Paulsen BaS, R de Moraes Maciel, A Galina, M Souza da Silveira, C dos Santos Souza, H Drummond, E Nascimento Pozzatto, H Silva, L Chicaybam, R Massuda, P Setti-Perdigão, M Bonamino, PS Belmonte-de-Abreu, NG Castro, H Brentani and SK Rehen. (2012). Altered oxygen metabolism associated to neurogenesis of induced pluripotent stem cells derived from a schizophrenic patient. Cell Transplant 21:1547-1559.

11. Paulsen BaS, SC Cardoso, MP Stelling, DV Cadilhe and SK Rehen. (2014). Valproate reverts zinc and potassium imbalance in schizophrenia-derived reprogrammed cells. Schizophr Res 154:30-35.

12. Mitne-Neto M, M Machado-Costa, MC Marchetto, MH Bengtson, CA Joazeiro, H Tsuda, HJ Bellen, HC Silva, AS Oliveira, M Lazar, AR Muotri and M Zatz. (2011). Downregulation of VAPB expression in motor neurons derived from induced pluripotent stem cells of ALS8 patients. Hum Mol Genet 20:3642-3652. 13. Beltrão-Braga PC, GC Pignatari, PC Maiorka, NA Oliveira, NF Lizier, CV Wenceslau, MA Miglino, AR Muotri and I Kerkis. (2011). Feeder-free derivation of induced pluripotent stem cells from human immature dental pulp stem cells. Cell Transplant 20:17071719.

14. de Carvalho Rodrigues D, KD Asensi,
L Vairo, RL Azevedo-Pereira, R Silva, E Rondinelli, RC Goldenberg, AC Campos de Carvalho and TP Urményi. (2012). Human menstrual blood-derived mesenchymal cells as a cell source of rapid and efficient nuclear reprogramming. Cell Transplant 21:2215-2224.

15. Asensi KD, RS Fortunato, DS Dos Santos, TS Pacheco, DF de Rezende, DC Rodrigues, FC Mesquita, TH KasaiBrunswick, AC de Carvalho, DP Carvalho, AB Carvalho and $\mathrm{RC}$ Goldenberg. (2014). Reprogramming to a pluripotent state modifies mesenchymal stem cell resistance to oxidative stress. J Cell Mol Med 18:824-831.

\section{Websites}

101. Folha de São Paulo. Brasil terá primeiro teste clinico com células embrionarias. www1.folha.uol.com. br/ciencia/2013/08/1329467-brasil-teraprimeiro-teste-clinico-com-celulasembrionarias.shtml 102. Rede Nacional de Terapia Celular. www.rntc.org.br 